\title{
The Behavior of a Strengthened Steel Beam Section Under Eccentric Loadings
}

\author{
Mohammed M. Rasheed ${ }^{1, \mathrm{a}}$, Kamal Sh.Mahmoud ${ }^{1, \mathrm{~b}}$, Saad Khalaf Mohaisen ${ }^{1, \mathrm{c}^{*}}$, and \\ Mohammed Z. Yousif ${ }^{1, d}$ \\ ${ }^{1}$ Civil Engineering Department, Mustansiriyah University, Baghdad, Iraq \\ ammrk72@uomustansiriyah.edu.iq, bkamalshahada@uomustansiriyah.edu.iq, \\ ceng_saad@uomustansiriyah.edu.iq, ddr.mohammadalrawas@uomustansiriyah.edu.iq
}

\begin{abstract}
Thirteen simply supported steel samples have been tested to explain the effects of strengthening steel beams using an external prestressing strand. The samples have the same crosssectional dimensions and overall length. One steel beam without strengthening was taken as a reference, while the other twelve of them had been strengthening by two external strands at various eccentricity locations and jacking stresses. The strengthening by external prestressing strands is subdivided into two series according to jacking stress. Each series consists of six steel samples divided according to the eccentricity location of prestressing strand. During tests, it was found that the Load deflection response for the strengthened samples is stiffer as compared with the reference. The increasing percentage in ultimate load capacity was increased to $0.347,2.758,3.921,8.898,9.326$, and $10.256 \%$ for beams under jacking stress of $1120 \mathrm{MPa}$, while increasing percentage in ultimate load capacity were increased to $0.17,26,33,48.5,13.7$, and $69.56 \%$ for beams under jacking stress of $815 \mathrm{MPa}$. On the other hand, the maximum percentages of deflection were decreased to 4.88, 2.44, $20.62,15$, and $9.7 \%$ when the jacking stress increase from 815 to $1120 \mathrm{MPa}$ and the ratio of the quarter to mid-span deflection $(\delta$ quarter $/ \delta$ mid) is about 0.528 and 0.497 when jacking stress is 1120 and $815 \mathrm{MPa}$ respectively. So, the increase in jacking stresses from 815 to $1120 \mathrm{MPa}$ will not be preferable because it has a little increasing percentage in stiffening and behaviors compared with other tested beams at the same condition.
\end{abstract}

Keywords: Strengthening of steel beams; deflection behavior; pre-stressing; eccentricity of strand; jacking's stress.

\section{Introduction}

Post-tensioning form where the strands are located outside the cross-sectional area called an external prestressing and prestress force can be transported to the structural member through the deviators and anchorages. External prestressing is one of the best methods to strengthen and rehabilitate the old structural members. In general, it is utilized to develop bridges and buildings for the expected overloading design and fatigue state [1]. The external prestressing concept of the steel beams has been accomplished using the strand of high strength, which is anchored at both steel beam ends. A specific amount of the saddles may be fixed to the length of the internal span through strand profile that it stops the occurrence of the slipping in a strand, and it helps give the shape of the design profile of external prestressing strand (parabolic or draped) according to applied loads and bending moment diagrams [2].

The strand has been tensioned after that from one end simultaneously with the use of the same force of jacking utilized in prestressing strand tensioning. To prevent biaxial bending and specimen distortions, careful care has to be taken to balance the prestressing force in strands $[3,4]$.

\section{Tested Program}

Sample Descriptions. This paper aims to focus on prestressing strand, the eccentricity locations, and jacking stresses (fpi). The steel samples are divided into two groups in accordance with the presence of prestressing strand. The first group included one steel sample and was considered as a reference. On the other hand, the second group included twelve steel samples strengthened with prestressing 
strand and sub-divided into two series following jacking stresses (fpj). Each series included six beams distributed as the eccentricity of prestressing strand (e) extending from 0 to $165 \mathrm{~mm}$ under jacking stressed $\mathrm{fpj}=1120$ and $815 \mathrm{MPa}$.

Sample Identification: The tested samples were depended on the eccentricity of pre-stressing strand (e) and the amount of jacking stresses. The following coding was adopted:

$\mathrm{OX}_{0} \mathrm{X}_{1} \mathrm{X}_{2} \mathrm{X}_{3}$

Where:-

O: refer to original steel sample.

$\mathrm{O}_{\mathrm{X} 0}$ : refer to strengthened beam under different jacking stresses as follows:

$\mathrm{O}_{\mathrm{M}}$ : refer to strengthening beam under jacking stress $=1120 \mathrm{MPa}$.

$\mathrm{O}_{\mathrm{L}}$ : refer to strengthening beam under jacking stress $=815 \mathrm{MPa}$

$\mathrm{X}_{1}$ : refer to the eccentricity of prestressing strand at mid-span, defined as $(0,1$, and 2$)$

$\mathrm{X}_{2}$ : refer to the eccentricity of prestressing strand at end span, defined as $(0,1,2$, and 3$)$

$\mathrm{X}_{3}$ : refer to the eccentricity of prestressing strand at effective depth, defined as $(0,1,2,3,4$, and 5)

All definition of samples which used in this research are shown in Figure 1 and Table 1.

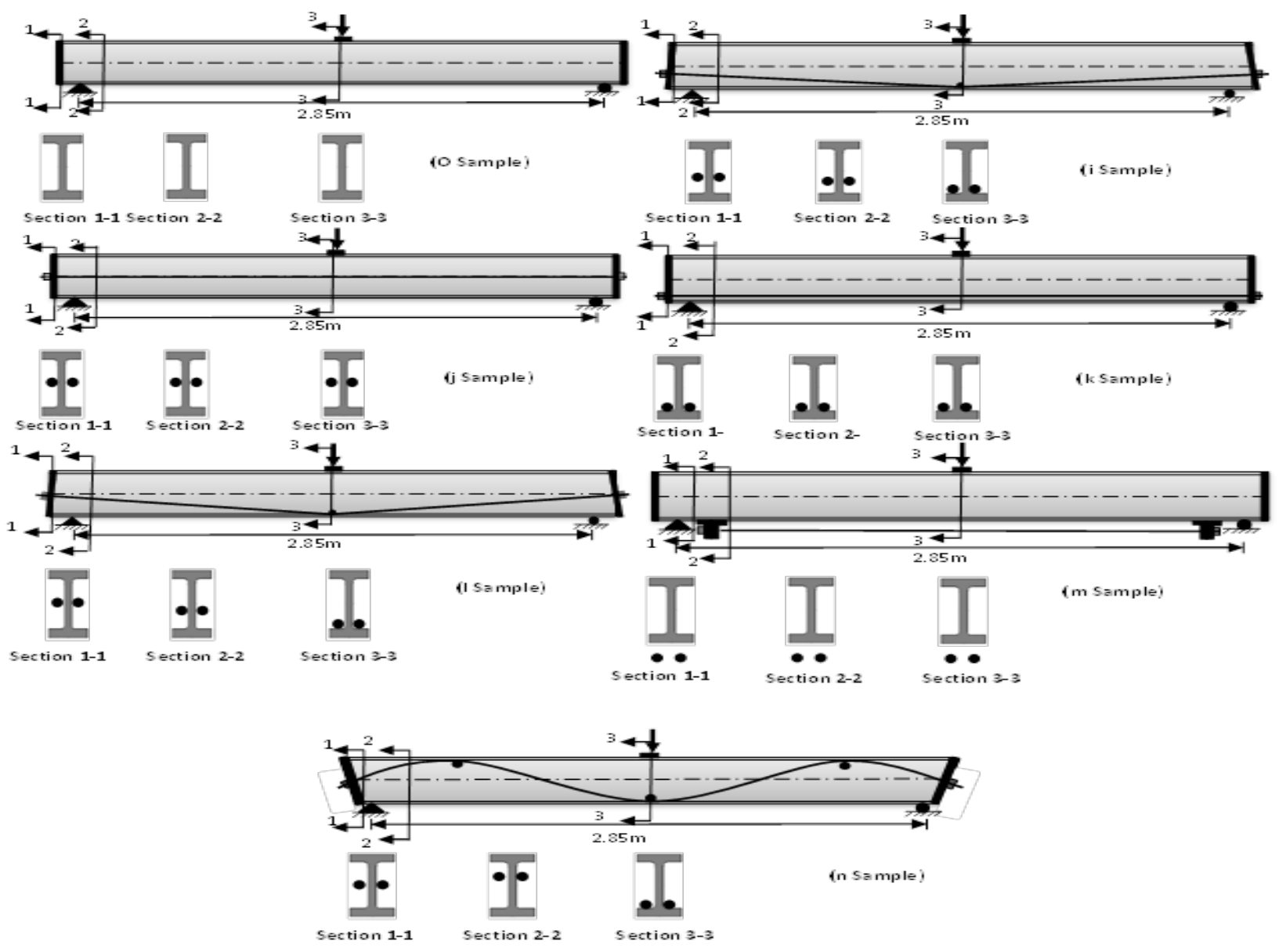

Figure 1. Samples descriptions. 
Table 1. Samples identification.

\begin{tabular}{|c|c|c|c|c|c|c|c|c|c|}
\hline \multirow{2}{*}{$\stackrel{\mathscr{Z}}{0}$} & \multirow{2}{*}{ 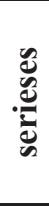 } & \multirow{2}{*}{ 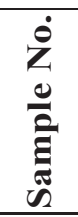 } & \multirow{2}{*}{ 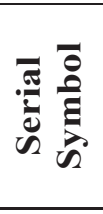 } & \multirow{2}{*}{$\begin{array}{l}\text { Prestressing } \\
\text { Strand Profile }\end{array}$} & \multirow{2}{*}{$\begin{array}{c}\text { Sample } \\
\text { Shape }\end{array}$} & \multirow{2}{*}{$\begin{array}{c}\text { Jacking } \\
\text { Stresses (f f pj) } \\
\quad(\mathrm{MPa})\end{array}$} & \multicolumn{3}{|c|}{$\begin{array}{c}\text { Eccentricity (e) } \\
(\mathbf{m m})\end{array}$} \\
\hline & & & & & & & $\mathbf{e}_{1}$ & $\mathbf{e}_{2}$ & $\mathbf{e}_{3}$ \\
\hline 1 & 1 & Ref. & $\mathrm{O}$ & ---- & $\stackrel{!}{\square}$ & ---- & ---- & ---- & ---- \\
\hline \multirow{12}{*}{2} & \multirow{6}{*}{2} & 1 & $\mathrm{OM}_{\mathrm{i}}$ & Straight & & 1120 & 0 & 0 & 0 \\
\hline & & 2 & $\mathrm{OM}_{\mathrm{j}}$ & Draped & $\stackrel{1}{2}$ & 1120 & 96 & 0 & 19.51 \\
\hline & & 3 & $\mathrm{OM}_{\mathrm{k}}$ & Draped & $\stackrel{1}{2}$ & 1120 & 96 & 20 & 35.45 \\
\hline & & 4 & $\mathrm{OM}_{\mathrm{L}}$ & Straight & E & 1120 & 96 & 96 & 96 \\
\hline & & 5 & $\mathrm{OM}_{\mathrm{m}}$ & Straight & & 1120 & 165 & 165 & 165 \\
\hline & & 6 & $\mathrm{OM}_{\mathrm{n}}$ & Sinewave & & 1120 & 96 & 0 & -39 \\
\hline & \multirow{6}{*}{3} & 7 & $\mathrm{OL}_{\mathrm{i}}$ & Straight & 1 & 815 & 0 & 0 & 0 \\
\hline & & 8 & $\mathrm{OL}_{\mathrm{j}}$ & Draped & 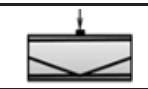 & 815 & 96 & 0 & 19.51 \\
\hline & & 9 & $\mathrm{OL}_{\mathrm{k}}$ & Draped & $\stackrel{1}{2}$ & 815 & 96 & 20 & 35.45 \\
\hline & & 10 & $\mathrm{OL}_{\mathrm{L}}$ & Straight & & 815 & 96 & 96 & 96 \\
\hline & & 11 & $\mathrm{OL}_{\mathrm{m}}$ & Straight & $\stackrel{1}{\square}$ & 815 & 165 & 165 & 165 \\
\hline & & 12 & $\mathrm{OL}_{\mathrm{n}}$ & Sinewave & $\stackrel{1}{\pi}$ & 815 & 96 & 0 & -39 \\
\hline
\end{tabular}

Where: $\mathrm{e}_{1}=$ middle eccentricity, $\mathrm{e}_{2}=$ end eccentricity, $\mathrm{e}_{3}=$ effective depth eccentricity, $\mathrm{OM}_{\text {sub. }}, \mathrm{OL}_{\text {sub.: }} \mathrm{O}=$ Reference steel beam, $\mathrm{M}=$ Initial Jacking's Stress (1120. MPa), L=Initial Jacking's Stress (814.6) MPa, i, j, k, L, m, and n.= Identification of eccentricity location. Note: negative sign mean $\mathrm{e}_{3}$ is above the neutral axis of the section.

Materials and Testing: The steel section material depends on the specification of the selected I hot rolled steel section. The mechanical results of the section are listed in Table 2.

Table 2. Mechanical Characteristics

\begin{tabular}{|c|c|c|c|c|}
\hline Standards & Sample No. & $\begin{array}{c}\text { Yielding Stress } \\
\left(\mathbf{f}_{\mathbf{y}}\right) \mathbf{( M P a )}\end{array}$ & $\begin{array}{c}\text { Ultimate Tensile Stress } \\
\left(\mathbf{f}_{\mathbf{u}}\right) \mathbf{( M P a )}\end{array}$ & $\begin{array}{c}\text { Total Elongation } \\
(\mathbf{\%})\end{array}$ \\
\hline \multirow{3}{*}{} & PL 10 & 360 & 507 & 15.9 \\
\cline { 2 - 5 } & PL 20 & 356 & 524 & 25.2 \\
\cline { 2 - 5 } & PL 30 & 369 & 507 & 17.5 \\
\hline Average value & 362 & 513 & 19.6 \\
\hline \multicolumn{2}{|c|}{ American ASTM } & $250 \geq$ & $400 \geq$ & $20 \geq$ \\
\hline
\end{tabular}

On the other hand, I-section can be defined as an element with a cross-sectional area similar to the letter $\mathrm{H}$ and has been considered the most commonly utilized structural member. It has been designed so that the flanges can provide the strength of the horizontal plate, whereas the web provides the strengthening in the vertical plate [9]. Table 3 lists the steel section's geometrical details, whereas the end steel plate may be welded directly to the steel beam with the use of welding. Those are $5 \mathrm{~mm}$ 
fillet welds that the E-7018 electrodes have made. Those end plates include 2 holes to allow the strand of the prestressing to be passing through them [11-13].

Table 3. The steel section's geometrical details [15].

\begin{tabular}{|c|c|c|c|c|c|c|c|c|c|c|c|}
\hline \multirow{2}{*}{$\begin{array}{c}\begin{array}{c}\text { Size } \\
\mathbf{m m}\end{array} \\
\mathrm{H} \times \mathrm{B} \\
\end{array}$} & \multicolumn{2}{|c|}{$\begin{array}{c}\text { Thickness } \\
\text { mm }\end{array}$} & \multirow{2}{*}{\begin{tabular}{|c|}
$\begin{array}{c}\text { Radius } \\
\text { of curvature } \\
\text { mm }\end{array}$ \\
R \\
\end{tabular}} & \multirow{2}{*}{ 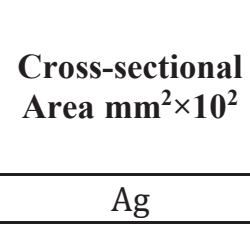 } & \multirow[t]{2}{*}{$\begin{array}{c}\text { Mass } \\
\text { per } \\
\text { meter } \\
\mathrm{kg} / \mathrm{m}\end{array}$} & \multicolumn{2}{|c|}{$\begin{array}{l}\text { Moment } \\
\text { of inertia } \\
\text { mm }^{4} \times 10^{4}\end{array}$} & \multicolumn{2}{|c|}{$\begin{array}{c}\text { Gyration } \\
\text { Radius } \\
\text { mm }\end{array}$} & \multicolumn{2}{|c|}{$\begin{array}{c}\text { Modulus of } \\
\text { the Elastic } \\
\text { section } \\
\mathrm{mm}^{3} \times 10^{3} \\
\end{array}$} \\
\hline & $t_{1}$ & $t_{2}$ & & & & $\mathrm{I}_{\mathrm{x}-\mathrm{x}}$ & $\mathrm{I}_{\mathrm{y}-\mathrm{y}}$ & $\mathrm{r}_{\mathrm{x}}$ & $\mathrm{r}_{\mathrm{y}}$ & $S_{x}$ & $\mathrm{~S}_{\mathrm{y}}$ \\
\hline $248 \times 124$ & 8 & 5 & 12 & 32.68 & 25.7 & 3540 & 255 & 104 & 27.9 & 285 & 41.1 \\
\hline
\end{tabular}

\section{Prestressing Steel Strands}

Two low relaxation 7-wire strands grade 270 have been used to strengthen the section and have been confirmed according to ASTM A 416/A416M-12 [14]. The strand characteristics have been illustrating in Fig. 2.

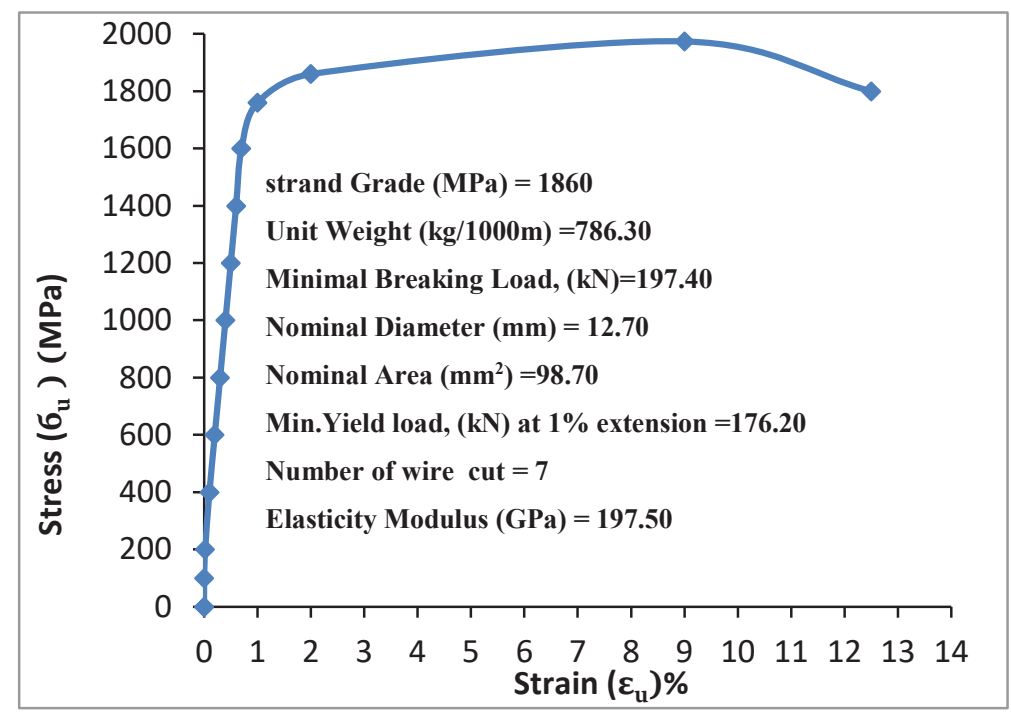

Figure 2. Stress -strain curve for strands.

Jacking Stresses: The strands have been fixed at different locations from the neutral axis of the steel section, varying from 0-165 mm. 275 and 200 bar. Jacking stress levels were used, and then the jacking stress was converted to 1120 and $815 \mathrm{MPa}$. A hydraulic jacking machine was used to pull the strands, as shown in Figure 3.

Measurements of the Load- Deflection and Test Process: The test of the steel beams have been conducted in the structural Lab. of Civil Eng. Dept., at the Engineering College, Al-Mustansiriyah University. The machine that has been utilized for the testing was the (MFL) universal hydraulic machine which has a capacity of $(3000 \mathrm{kN})$. The steel beam has a $2850 \mathrm{~mm}$ clear span. A steel bearing plate $(12 \times 100 \mathrm{~mm})$ has been utilized to convert the concentrated load to line load. Dial gauges with an accuracy of $(0.01 \mathrm{~mm})$ and a $(30 \mathrm{~mm})$ capacity have been fixed at the mid and quarter span. At first, a load of $(5 \mathrm{kN})$ has been applied and removed to re-check zero reading cases. Measurements have been taken at every $(10 \mathrm{kN})$ increment with a load step $(2 \mathrm{kN})$. The measurements have been recorded up to the failure occurs where the applied load drops with an increase in the deformation, the instrumentation details, and the testing machine shown in Figure 4. 


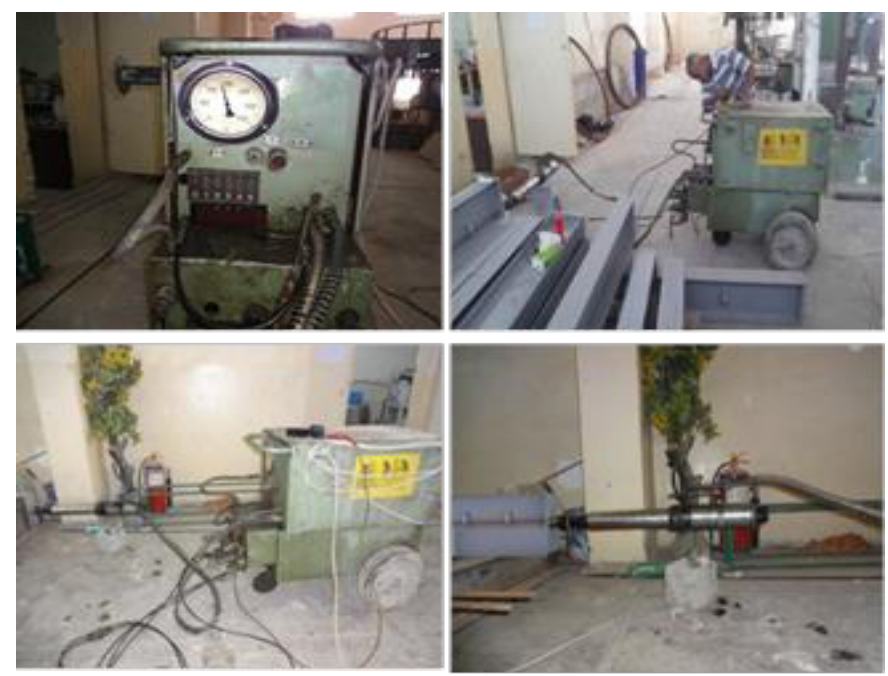

Figure 3. Prestressing hydraulic machine.

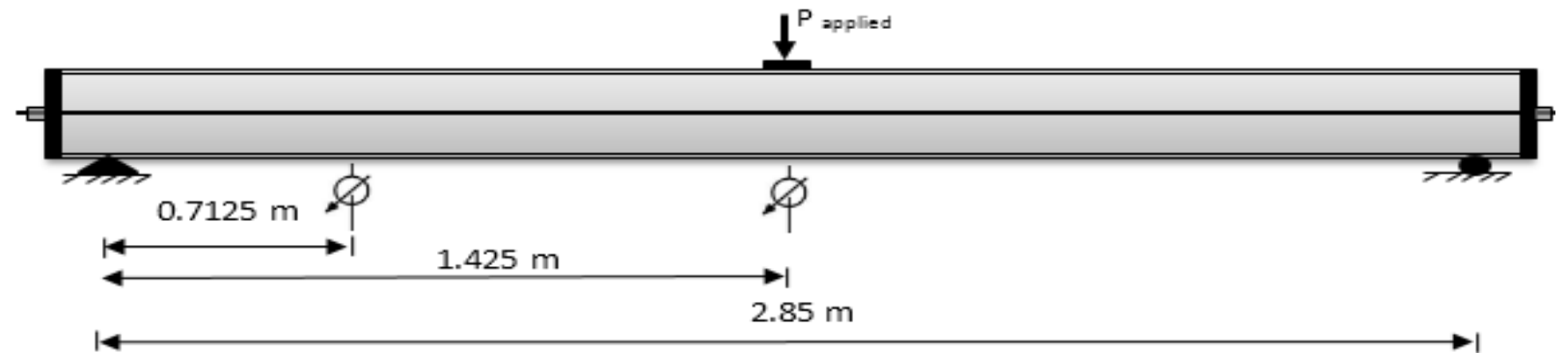

A-Locations of dial gauges for tested beams
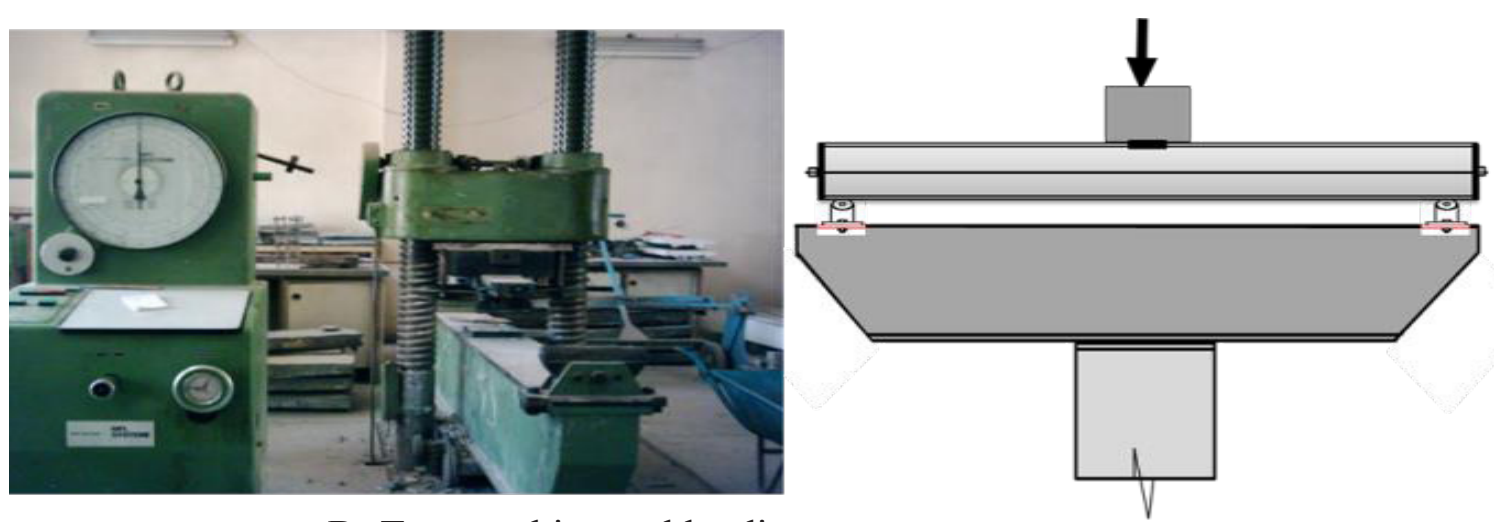

B- Test machine and loading arrangements

Figure 4. A- Locations of dial gauges for tested sample, B- testing machine, and the loading arrangements.

\section{Discussion of Results}

Load Deflection Response: During the test, it can be observed that the load-deflection curves for strengthened samples are stiffer as compare with the reference sample. The percentage of stiffening increases with increasing in eccentricity locations. Due to an external prestressing strand, which improved the web resistance and bottom flange, it also contributes to resisting the applied load, as shown in Error! Reference source not found. and 6 [7]. 

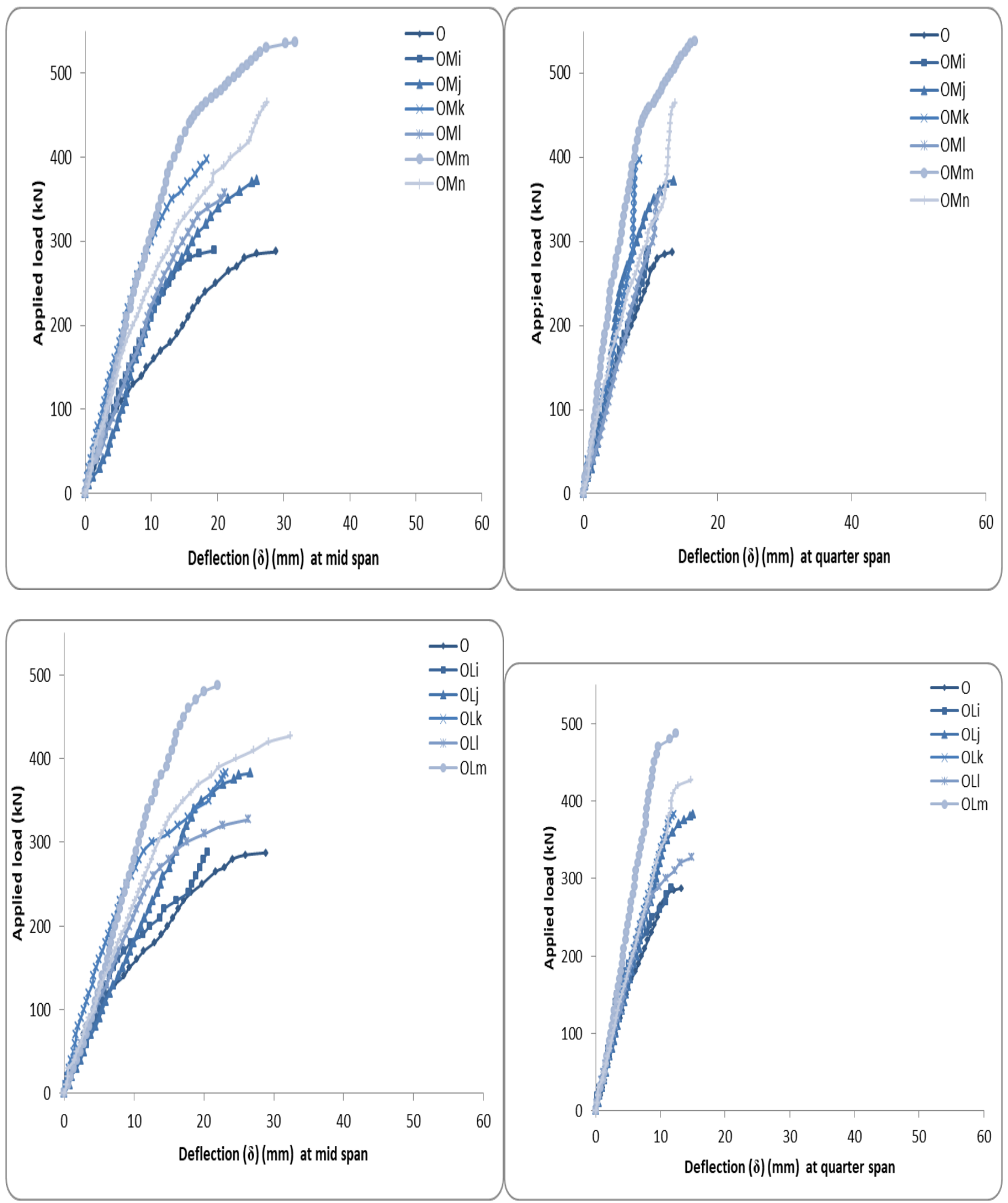

Figure 5. Load deflection curves for tested samples.

Ultimate Load Capacity: During the tests, it was found that ultimate load capacity increased to 0.52 , $29.56,38.26,61.74,24.35$, and $86.96 \%$ with an increase in the locations of eccentricity from $(0 \mathrm{~mm}$ to $165 \mathrm{~mm}$ ) respectively at $\mathrm{fpj}=1120 \mathrm{MPa}$ in comparison to reference sample, whereas, at $\mathrm{fpj}=815$ $\mathrm{MPa}$, the increasing percentage in the maximal applied load is increased to $0.17,26,33,48.5,13.74$, and $69.6 \%$ ). So, it was found that ultimate load capacity for tested samples was increased when the eccentricity was increased at the same fpj, that as a result of the existence of an external prestressing strand which enhanced bottom flange and web resistance and it played a role as well in enabling steel 
beams in resisting applied loads. [4,6,7]. The ultimate load capacity of the tested samples is listed in Table 4 and shown in Figure 6.

Table 4. Ultimate Load Capacity of tested beams.

\begin{tabular}{|c|c|c|c|c|}
\hline $\begin{array}{c}\text { Beams } \\
\text { Number }\end{array}$ & $\begin{array}{c}\text { Series } \\
\text { Symbol }\end{array}$ & $\begin{array}{c}\text { Jacking's } \\
\text { Stresses, (fpj) } \\
(\mathbf{M P a})\end{array}$ & $\begin{array}{c}\text { Ultimate Exp. } \\
\text { applied load (Pu) } \\
(\mathbf{k N})\end{array}$ & $\begin{array}{c}\text { Percentage of ultimate load } \\
\text { (\%) as compared with the } \\
\text { reference }\end{array}$ \\
\hline 1 & $\mathrm{O}$ & ----- & 287.5 & 0 \\
\hline 2 & $\mathrm{OM}_{\mathrm{i}}$ & 1120 & 289.0 & 0.52 \\
\hline 3 & $\mathrm{OM}_{\mathrm{j}}$ & 1120 & 372.5 & 29.57 \\
\hline 4 & $\mathrm{OM}_{\mathrm{k}}$ & 1120 & 397.5 & 24.26 \\
\hline 5 & $\mathrm{OM}_{\mathrm{L}}$ & 1120 & 357.5 & 86.96 \\
\hline 6 & $\mathrm{OM}_{\mathrm{m}}$ & 1120 & 537.5 & 61.74 \\
\hline 7 & $\mathrm{OM}_{\mathrm{n}}$ & 1120 & 465.0 & 0.17 \\
\hline 8 & $\mathrm{OL}_{\mathrm{i}}$ & 815 & 288.0 & 26.09 \\
\hline 9 & $\mathrm{OL}_{\mathrm{j}}$ & 815 & 362.5 & 33.04 \\
\hline 10 & $\mathrm{OL}_{\mathrm{k}}$ & 815 & 382.5 & 13.74 \\
\hline 11 & $\mathrm{OL}_{\mathrm{L}}$ & 815 & 327.0 & 69.57 \\
\hline 12 & $\mathrm{OL}_{\mathrm{m}}$ & 815 & 487.5 & 48.52 \\
\hline 13 & $\mathrm{OL}_{\mathrm{n}}$ & 815 & 427.0 & \\
\hline
\end{tabular}

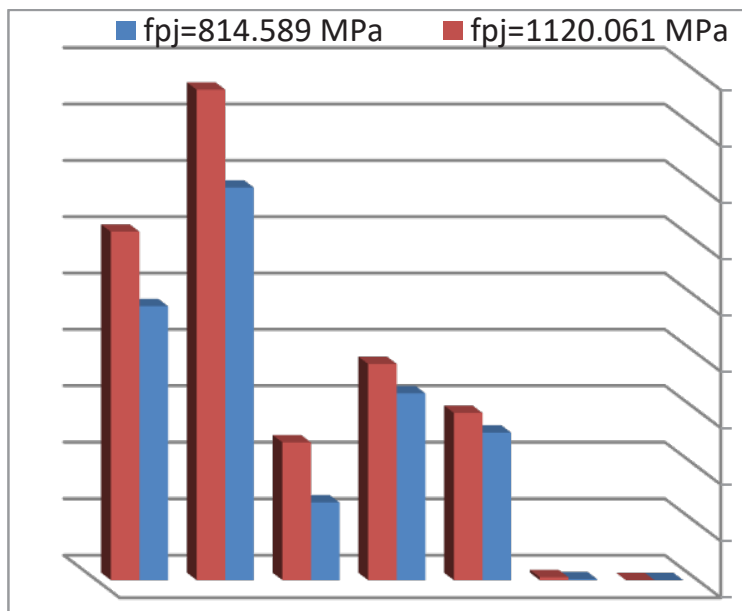

$\mathrm{n}$ $\mathrm{m}$

$\begin{array}{lll}\mathrm{L} & \mathrm{k} & \mathrm{j}\end{array}$

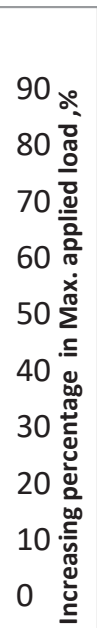

0

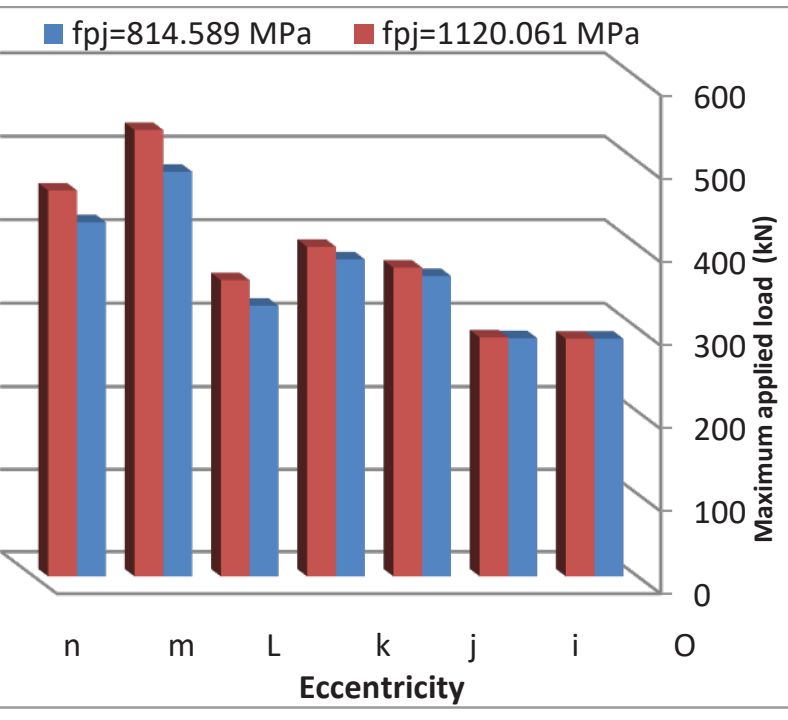

Figure 6. Ultimate load capacity and Percentages increase the ultimate load of tested beams.

Mid and Quarter Deflection Values: During the test, it was noted that at $f p j=1120 \mathrm{MPa}$, the percentage increasing in mid-span deflection was decreased to $32.5,10.3,36.3,4.8$, and 26.9\% when the eccentricity increased from 0 to $165 \mathrm{~mm}$, respectively, as compared with a reference sample, while, at $\mathrm{fpj}=815 \mathrm{MPa}$, the increasing percentage in mid-span deflection was decreased to $29.1,7.75$, $19.76,11.98,8.97$, and $23.78 \%$ when the eccentricity increased from 0 to $165 \mathrm{~mm}$, respectively as compared with reference sample too, and the ratio of the quarter span to mid-span deflection ( $\delta$ quarter $/ \delta \mathrm{mid}$ ) is about 0.528 and 0.497 when fpj is 1120 and $815 \mathrm{MPa}$ respectively. So, the maximum deflection at mid-span is decreased when the eccentricity increased at the same fpj as a result of existing of prestressing strand, which improves the web resistance near the bottom flange, and it contributes with the steel section to withstand the applied loading as listed in Table 5 and shown Figures 7 to $11[4,6,7]$. 
Table 5. Increasing percentage in maximum deflection for tested beams.

\begin{tabular}{|c|c|c|c|c|c|}
\hline \multirow{2}{*}{$\begin{array}{c}\text { Beams } \\
\text { No. }\end{array}$} & \multirow{2}{*}{$\begin{array}{c}\text { Series } \\
\text { Symbols }\end{array}$} & \multicolumn{2}{|c|}{$\delta \max .(\mathrm{mm})$ at } & \multirow{2}{*}{\begin{tabular}{|c|}
$\%$ increase in maximum \\
deflection for tested \\
beams $\%$
\end{tabular}} & \multirow{2}{*}{ 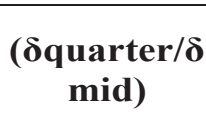 } \\
\hline & & Quarter span & Midspan & & \\
\hline Ref.1 & $\mathrm{O}$ & 13.20 & 28.89 & 0 & 0.456 \\
\hline 1 & $\mathrm{OM}_{\mathrm{i}}$ & 9.70 & 19.50 & -32.50 & 0.497 \\
\hline 2 & $\mathrm{OM}_{\mathrm{j}}$ & 13.45 & 26.00 & -10.00 & 0.517 \\
\hline 3 & $\mathrm{OM}_{\mathrm{k}}$ & 8.35 & 18.40 & -36.31 & 0.453 \\
\hline 4 & $\mathrm{OM}_{\mathrm{L}}$ & 11.40 & 21.12 & -26.89 & 0.539 \\
\hline 5 & $\mathrm{OM}_{\mathrm{m}}$ & 16.60 & 31.75 & 9.90 & 0.522 \\
\hline 6 & $\mathrm{OM}_{\mathrm{n}}$ & 13.65 & 27.50 & -4.81 & 0.496 \\
\hline 7 & $\mathrm{OL}_{\mathrm{i}}$ & 11.70 & 20.50 & -29.04 & 0.570 \\
\hline 8 & $\mathrm{OL}_{\mathrm{j}}$ & 15.00 & 26.65 & -7.75 & 0.562 \\
\hline 9 & $\mathrm{OL}_{\mathrm{k}}$ & 12.10 & 23.18 & -19.76 & 0.522 \\
\hline 10 & $\mathrm{OL}_{\mathrm{L}}$ & 14.85 & 26.30 & -8.97 & 0.564 \\
\hline 11 & $\mathrm{OL}_{\mathrm{m}}$ & 12.40 & 22.02 & -23.78 & 0.563 \\
\hline 12 & $\mathrm{OL}_{\mathrm{n}}$ & 14.75 & 32.35 & 11.98 & 0.455 \\
\hline
\end{tabular}
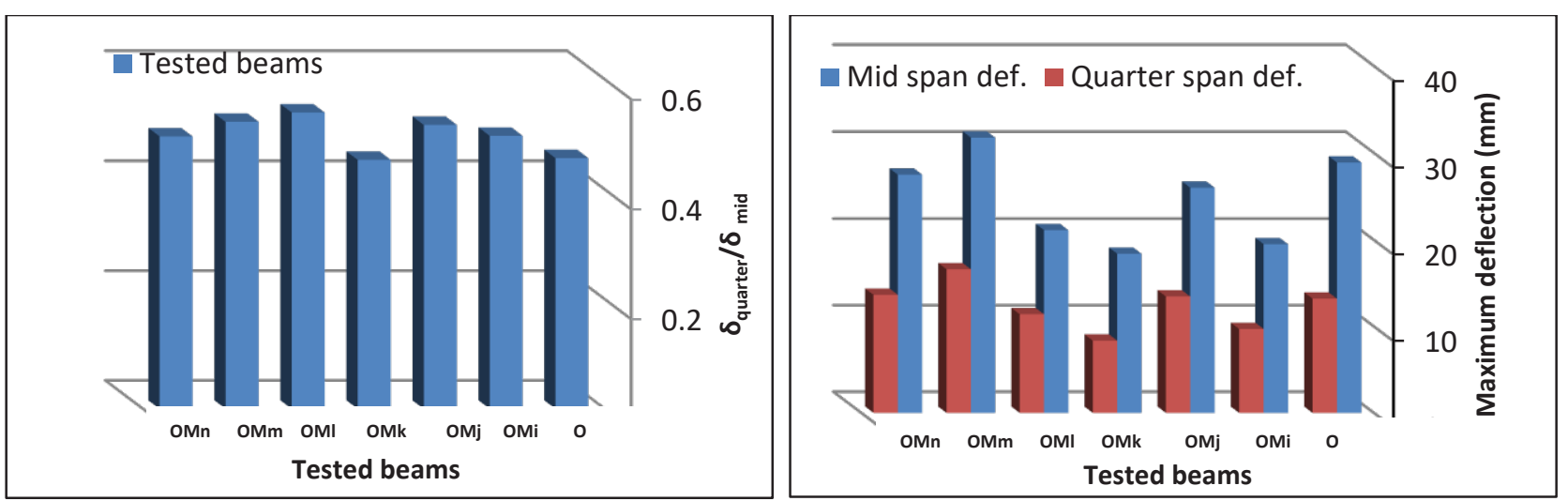

Figure 7 . The $\left(\delta_{\text {quarter }} / \delta_{\text {mid }}\right)$ for tested samples.

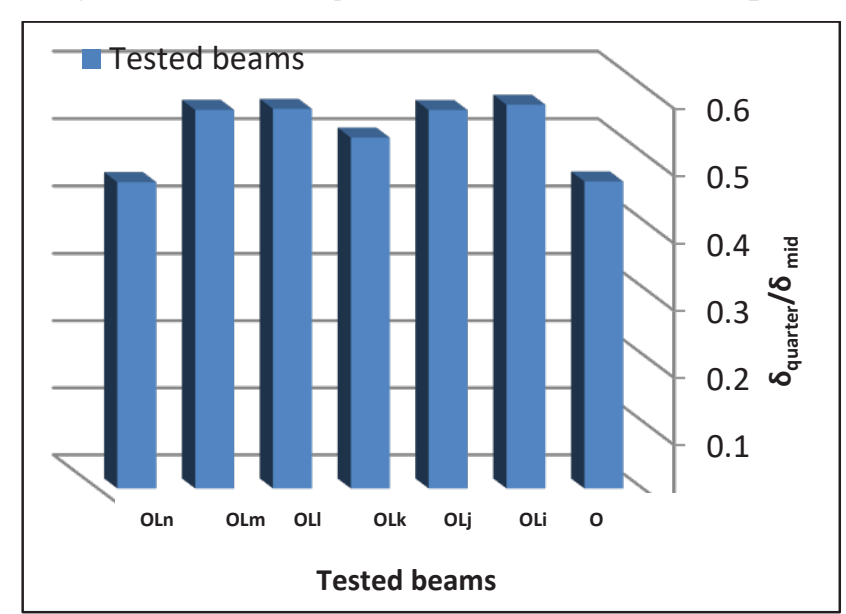

Figure 8. Deflection values of tested samples.

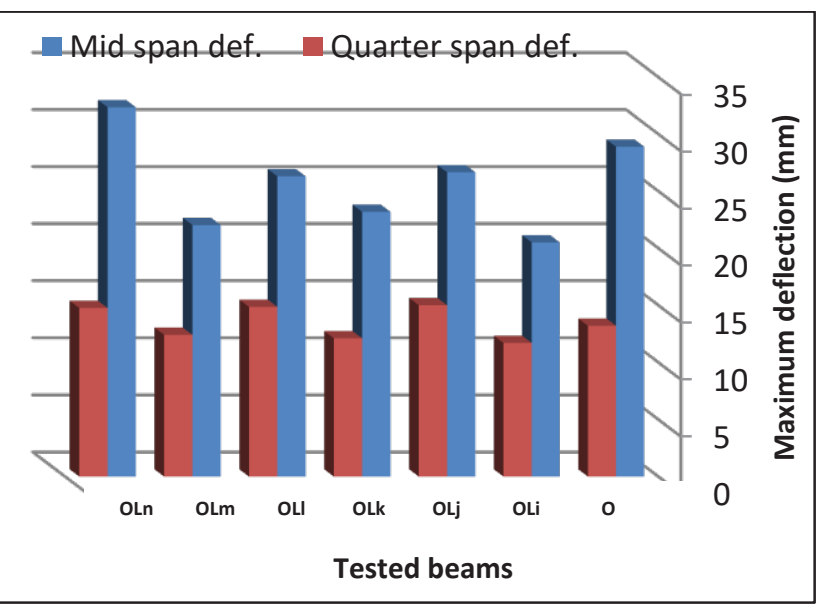

Figure 9. The $\left(\delta\left(\delta_{\text {quarter }} / \delta_{\text {mid }}\right)\right.$ for tested samples. Figure 10. Deflection values of tested samples. 


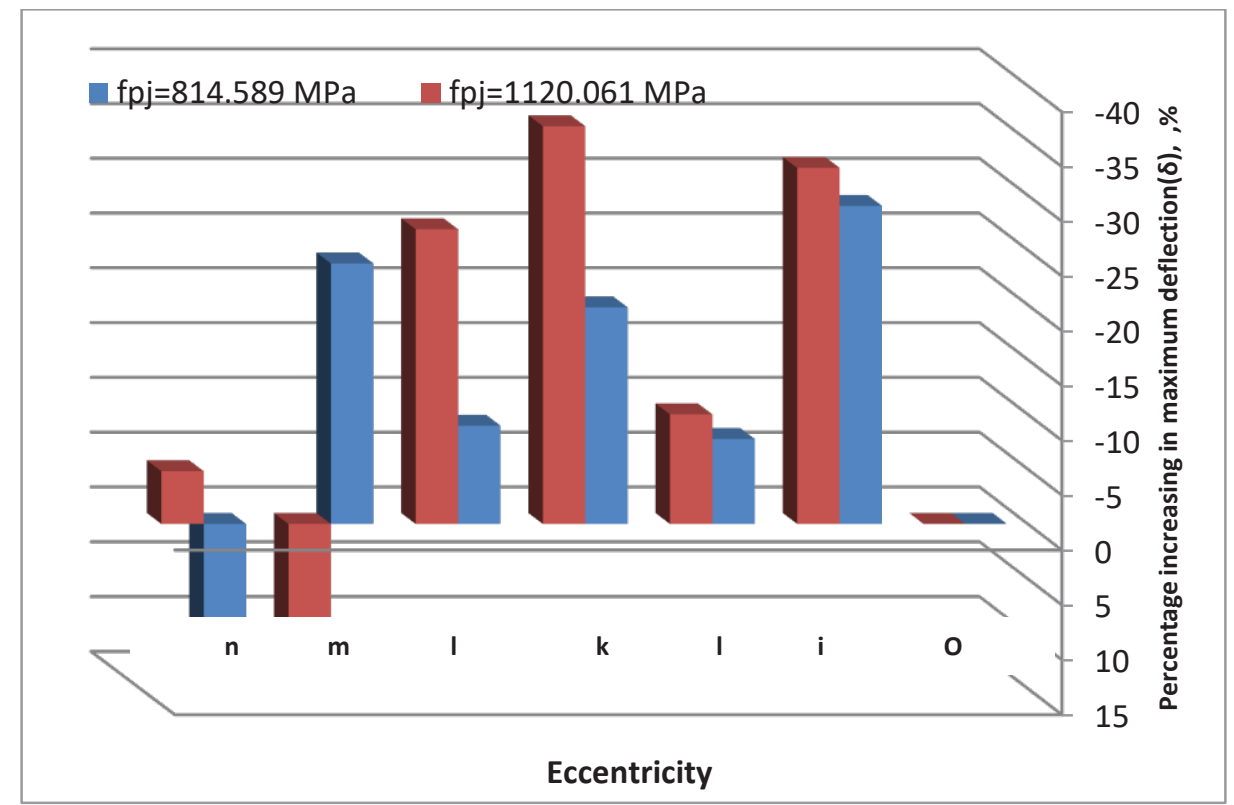

Figure 11. Increasing percentages in maximum deflection for tested samples.

\section{Conclusions}

Depending on the experimental results of tested samples, the summaries of findings are as follows.

- Load deflection response for the strengthened samples is stiffer as compared with the reference.

- Increasing the percentage in the ultimate load capacity was $0.347,2.758,3.921,8.898,9.326$, and $10.256 \%$, respectively, when the eccentricity rises from 0 to $165 \mathrm{~mm}$ under jacking stress of $1120 \mathrm{MPa}$.

- The increasing percentage in the ultimate load capacity was $0.17,26,33,48.5,13.7$, and $69.56 \%$, respectively, when the eccentricity increased from 0 to $165 \mathrm{~mm}$ under the jacking stress of $815 \mathrm{MPa}$.

- Maximum percentages of deflection were decreased to $4.88,2.44,20.62,15.0$, and $19.7 \%$ when the jacking stress increase from 815 to $1120 \mathrm{MPa}$

- The quarter's ratio to mid-span deflection $\left(\delta_{\text {quarter }} / \delta_{\text {mid }}\right)$ is about 0.528 and 0.497 when jacking stress was $1120 \mathrm{MPa}$ and $815 \mathrm{MPa}$, respectively.

- The increase in jacking stresses from 815 to $1120 \mathrm{MPa}$ will not be preferable because it has a little increasing percentage in stiffening and behaviors compared with other tested beams at the same condition at jacking stress $(\mathrm{fpj}=815 \mathrm{MPa})$.

\section{Acknowledgment}

The authors would like to thank the staff of Mustansiriyah University (www.uomustansiriyah.edu.iq), Baghdad-Iraq, for support in the present work.

\section{References}

[1] Ghallab, A. and Beeby, A.W., 2005. Factors affecting the external prestressing stress in externally strengthened prestressed concrete beams. Cement and Concrete Composites, 27(910), pp.945-957.

[2] Harajli, M.H., 1993. Strengthening of concrete beams by external prestressing. PCI Journal, 38(6), pp.76-88.

[3] Salamone, S., Bartoli, I., Phillips, R., Nucera, C. and Di Scalea, F.L., 2011. Health monitoring of prestressing tendons in posttensioned concrete bridges. Transportation research record, 2220(1), pp.21-27 
. [4] Mahmoud, K.S., Rasheed, M.M. and Mohaisen, S.K., 2020. Strengthening of I-section steel beams by prestressing strands. In Key Engineering Materials (Vol. 857, pp. 169-176). Trans Tech Publications Ltd.

6] Yousif, M.A., Mahmoud, K.S. and Atshan, A.F., 2020. The Effect of prestressing strands on the shear behaviours of steel beams. In IOP Conference Series: Materials Science and Engineering (Vol. 671, No. 1, p. 012152). IOP Publishing.

[7] Mahmoud, K.S., Rasheed, M.M. and Khalaf, S., 2020. Strengthening behavior of steel beams under varied eccentricity locations and jacking stress. Journal of Engineering and Sustainable Development, 24(01).

[9] Sulamet-Ariobimo, R.D., Soedarsono, J.W., Sukarnoto, T., Rustandi, A., Mujalis, Y. and Prayitno, D., 2016. Tensile properties analysis of AA1100 aluminium and SS400 steel using different JIS tensile standard specimen. Journal of applied research and technology, 14(2), pp.148-153.

[10] Daly, A.F. and Woodward, R.J., 2000. Strengthening of concrete structures using external posttensioning. Annex L, Rehabcon, Strategy for Maintenance and Rehabilitation. IPS-2000-0063. Available online at http://www. civil. ist. utl. pt/ cristina/RREst/Annex_L. pdf.

[11] Roger Brockenbrough, P.E. and Merritt, F.S., 2011. Structural steel designer's handbook. McGraw-Hill Education.

[12] American Institute of Steel Construction, 2005. Steel construction manual. Amer Inst of Steel Construction.

[13] ASTM, A370., 2014. Standard testing method and definitions for mechanical testing of steel products. ASTM International, Pennsylvania, United States.

[14] Standard, A.S.T.M., 2012. C618-12a, Standard Specification for coal fly ash and raw or calcined natural Pozzolan for use in concrete. 2012 Annual Book of ASTM Standards; American Society for Testing and Materials (ASTM): West Conshocken, PA.

[15] Mahmoud, K.S., Yousif, M.A. and Rasheed, M.M., 2020, February. Effect of external prestressing strands on the Yielding Stage behaviours of steel beams. In IOP Conference Series: Materials Science and Engineering (Vol. 737, No. 1, p. 012032). IOP Publishing. 